Dr DRAGOMIR BONDŽIĆ, viši naučni saradnik

Institut za savremenu istoriju

Beograd, Trg Nikole Pašića 11

dragomirbondzic@ptt.rs

UDK 327.5:623.454.8(540)"1974"

327(497.1:540)"1974"

originalan naučni rad

primljeno: 30. oktobar 2015.

prihvaćeno: 16. novembar 2015.

\title{
INDIJSKA NUKLEARNA PROBA 1974. GODINE - ODJECI U JUGOSLAVIJI*
}

APSTRAKT: U radu se na osnovu građe Arhiva Jugoslavije i Diplomatskog arhiva Ministarstva spoljnih poslova Srbije analiziraju posledice prve indijske uspešne nuklearne probe maja 1974. na odnose Jugoslavije i Indije. $U$ prvom delu rada prate se reakcije i stavovi jugoslovenskih zvaničnika u kontaktima sa indijskim predstavnicima i u medunarodnim kontaktima, kao i stavovi drugih zemalja prema indijskoj probi. $U$ drugom delu se posmatra uticaj indijske nuklearne probe na oživljavanje jugoslovenskih nuklearnih ambicija i pokušaj intenziviranja naučne i tehničke saradnje Jugoslavije sa prvom nesvrstanom zemljom koja je postala nuklearna sila.

KLJUČNE REČI: Jugoslavija, Indija, atomska bomba, nuklearna proba, „nuklearna eksplozija za mir“, Pokret nesvrstanih, Josip Broz Tito

Ujutru u 8.05h 18. maja 1974. indijski naučnici su izvršili nuklearnu eksploziju kasnije nazvanu „Smiling Buddha“. Eksplozija je izvršena u pustinji kod mesta Pokhran (Pokhran), u pokrajini Radžastan (Rajasthan) u blizini granice sa Pakistanom, na oko 100 metara ispod zemlje. Kao gorivo je upotrebljen plutonijum, a snaga je iznosila 8-10 kilotona (oslobođena energija jednaka energiji 8.000-10.000 trinitrotoluola). Bomba bačena na Hirošimu 1945. imala je snagu 15-16 kilotona, bomba bačena na Nagasaki 21-25 tona, a Sovjeti su 1961. testirali hidrogensku bombu jačine čak 50 megatona. Indija je pokrenula civilni nuklearni program još 1944. pod nadzorom poznatog fizičara Homi J. Bhabhe i zahvaljujući velikim prirodnim bogatstvima, međunarodnoj saradnji i naporima domaćih naučnika u nare-

* Rad je deo projekta Srpsko društvo u jugoslovenskoj državi u 20. veku - između demokratije i diktature (br. 177016) koji finansira Ministarstvo prosvete, nauke i tehnološkog razvoja Republike Srbije. 
dnom periodu postigla značajne uspehe, postavila institucionalnu i kadrovsku bazu, savladala mnoge tehnološke postupke i izgradila niz nuklearnih uređaja (reaktore, elektrane, itd.). Od početka, međutim, Indija je bila motivisana i potragom za nuklearnim oružjem: od osnivanja je bila u sukobu sa susednim Pakistanom, sa kojim je 1947, 1965. i 1971. vodila ratove, a sa severa je bila pod stalnom pretnjom od NR Kine, od koje je 1962. poražena u pograničnom ratu i koja je od 1964. postala nuklearna sila. Da bi učvrstila svoj položaj u odnosu na susede i u regionu, da bi izbegla zavisnost od velikih sila (SAD i SSSR) i potvrdila svoj značaj kao velika zemlja i stara civilizacija, Indija je želela da postane i nuklearna sila. Zato su se sve vreme u okviru nuklearnog projekta pojavljivale težnje za proizvodnjom nuklearnog oružja, koje su se sredinom 60 -ih godina pretvorile u vojni nuklearni program koji je pod maskom „nuklearnog oružja za mir“, u strogoj tajnosti i uz povremene zastoje, krunisan uspehom i izvođenjem nuklearne eksplozije $1974 .{ }^{1}$

Iako su indijski zvaničnici i dalje insistirali da se radi o „nuklearnoj eksploziji u miroljubive svrhe“, Indija je ušla u "nuklearni klub“ i postala šesta nuklearna sila. Pre Indije to su postigli SAD (1945), SSSR (1949), Velika Britanija (1952), Francuska (1960) i Kina (1964). ${ }^{2}$ Time je u složenim hladnoratovskim međunarodnim odnosima u svetu i na Indijskom potkontinentu došlo do značajnog potresa. Pored promene odnosa snaga $u$ regionu, poseban značaj u međunarodnim odnosima imala je činjenica da je, posle Kine, veliki visoko-tehnološki uspeh ostvarila i u posed veoma opasnog oružja došla još jedna ekonomski nerazvijena zemlja sa velikim unutrašnjim društveno-ekonomskim i političkim problemima, i još uz to članica Pokreta nesvrstanih. ${ }^{3}$ Veliki značaj je imala i činjenica da je Indija bila prva zemlja koja je svoju nuklearnu probu izvršila posle sklapanja Sporazuma o zabrani širenja nuklearnog oružja (Nonproliferation Treaty NPT) iz 1968, kojem doduše sama Indija nije ni pristupila, smatrajući da

${ }^{1}$ Videti više u: George Perkovich, India's Nuclear Bomb: The Impact On Global Proliferation (Berkeley, Los Angeles and London: University of California Press, 1999); Abraham Itty, The Making of the Indian Atomic Bomb. Science, Secrecy, and the Postcolonial State (London and New York: Zed Books, 1998); Raj Chengappa, Weapons of Peace: the Secret Story of India's Quest to be a Nuclear Power (New Delhi: Harper Collins Publishers, 2000); http://nuclearweaponarchive.org/India/index.html (pristupljeno 18. 10. 2015). O odnosima Kine i Indije videti: Jovan Čavoški, Jugoslavija i kinesko-indijski konflikt 1959-1962 (Beograd: INIS, 2009).

${ }^{2}$ Jacques E. C. Hymans, Achieving Nuclear Ambitions. Scientists, Politicians, and Proliferation (New York: Cambridge University Press, 2012), 3.

${ }^{3}$ Hymans ispred indijske ekonomske zaostalosti i strane pomoći stavlja činjenicu da je indijski nuklearni projekat bio profesionalan, dobro organizovan i rukovođen, sa velikim brojem stručnih kadrova i sa racionalnom državnom administracijom nasleđenom iz kolonijalnog doba. Ibid., 20, 160-161, 199, 247. 
nijedna zemlja ne treba da se odrekne nuklearnog oružja pošto ga se ne odriču ni velike sile koje su ga već posedovale. Sve ovo je uticalo da na međunarodnoj sceni dođe do veoma živih reagovanja na vest o indijskoj nuklearnoj eksploziji $1974 .^{4}$

Posebno je bila značajna i reakcija Jugoslavije, koja je sa Indijom imala bliske i prijateljske odnose i intenzivnu saradnju u okviru Pokreta nesvrstanosti. Sredinom 70-ih godina Jugoslavija i Indija su se zajedno nametnule kao ključne zemlje u okviru Pokreta nesvrstanosti, obezbeđujući sinhronizovanu, jedinstvenu i efikasnu akciju ostalih članica te organizacije u Ujedinjenim nacijama i u široj sferi međunarodnih odnosa. Josip Broz i Indira Gandi su u to vreme ispoljavali visok stepen saglasnosti oko većine glavnih međunarodnih problema i oko razrešenja aktuelnih međunarodnih kriza i održavali su redovne kontakte kako bi razradili platformu buduće institucionalizacije zajedničkih aktivnosti vanblokovskih zemalja (formiranja prvih stalnih tela Pokreta nesvrstanosti). U tom sklopu posebno je bio važan susret Tita i Indire Gandi u Nju Delhiju, od 24. do 29. januara 1974, ${ }^{5}$ posle koga će uslediti čitav niz zajedničkih inicijativa Jugoslavije i Indije usmerenih na grananje institucionalnih mehanizama saradnje nesvrstanih zemalja i na njihove sve učestalije i sve ofanzivnije zajedničke nastupe $u$ sferi međunarodnih odnosa. Stoga je razdoblje koje je usledilo posle susreta Josipa Broza i Indire Gandi često karakterisano kao „zlatno doba“ nesvrstanosti. ${ }^{6} \mathrm{U}$ tom kontekstu treba posmatrati i stav Jugoslavije prema indijskoj nuklearnoj eksploziji maja 1974.

O prvom saznanju o indijskoj eksploziji jugoslovenski ambasador $\mathrm{u}$ Nju Delhiju Ilija Topalovski ${ }^{7}$ izvestio je Beograd već 18. maja 1974. Na hitan poziv Topalovski je došao $\mathrm{u}$ indijsko Ministarstvo inostranih poslova gde je primljen pre okupljenih ambasadora drugih zemalja („SSSR-a, Francuske, Nemačke, itd."). Saopšteno mu je da su indijski naučnici u jutarnjim časovima izveli podzemnu atomsku eksploziju i da ministar želi da „prijateljskim i drugim zemljama" saopšti vest koja će biti objavljena tokom dana.

${ }^{4}$ http://nuclearweaponarchive.org/India/index.html (pristupljeno 18. 10. 2015). Na unutrašnjem planu nuklearni program je posle početnog oduševljenja počeo da posustaje da bi tek kasnije bio oživljen i dovršen nuklearnom eksplozijom 1998, kada je Indija i formalno priznala da ima program usmeren u vojne svrhe (Ibid.; J. Hymans, Achieving Nuclear Ambitions, 273).

${ }^{5}$ Diplomatski arhiv Ministarstva spoljnih poslova Republike Srbije (DA MSP), Politička arhiva (PA), Jugoslavija, 1974, f-77, 48811. Titova poseta Indiji.

${ }^{6}$ Videti: Olivera Bogetić i Dragan Bogetić, Nastanak i razvoj pokreta nesvrstanosti (Beograd: Eksport pres, 1981).

${ }^{7}$ Ilija Topalovski (Bitolj, 1922 - Beograd, 1999), makedonski političar, učesnik NOB i ambasador SFRJ u Indiji 1973-1977. Bio je i ambasador u Tunisu (1958-1960), Gvineji (1960-1963), Norveškoj (1967-1970) i Japanu (1982-1986). Макеgонска енциклоиееgија, 2, редактор Блаже Ристовски (Скопје: МАНУ, 2009), 1495. 
Više puta je naglašeno da se radi isključivo o miroljubivoj upotrebi atomske energije i da se računa pre svega sa primenom u rudarstvu i eksploataciji rezervi gasa i obezbeđivanju daljih rezultata na naučnom i privrednom planu. ${ }^{8}$ Topalovski je čestitao i rekao da će javnost Jugoslavije „sa velikim zadovoljstvom primiti ovu vest i da je to veliki uspeh prijateljske, nesvrstane Indije“. U depeši upućenoj Saveznom sekretarijatu inostranih poslova dao je i napomenu da se radi o krupnom dostignuću i da je „očigledno da indijsko rukovodstvo želi da valorizuje ovaj rezultat i na političkom planu (što je sasvim prirodno)“. Prognozirao je da će objavljivanje ove vesti imati pozitivan odjek $u$ indijskoj javnosti, što je bilo veoma važno s obzirom na zategnuto stanje $u$ zemlji izazvano ekonomskim i drugim teškoćama (ishrana, cene, štrajkovi, nemiri), a obratio je pažnju i na međunarodne okolnosti, odnose Indije i Kine, problem Kašmira, itd. Na kraju je savetovao „da bi bilo dobro da se našoj štampi sugerira da se događaj proprati odgovarajućim komentarima". 9

Iako su prve reakcije u jugoslovenskoj štampi bile „odgovarajuće“, pometnju je uneo indijski list Times of India koji je 24. maja pod naslovom "Ne više nesvrstana" preneo vest agencije DPA po kojoj je Politika, "jugoslovenski vladin list“, pisala da je „indijska atomska eksplozija kompromitovala njenu poziciju nesvrstane zemlje“. ${ }^{10}$ Pokazalo se da su izveštaji drugih agencija iz Beograda bili sasvim različiti. Zato su službenici jugoslovenske ambasade u kontaktima sa indijskim zvaničnicima i službenicima agencija zaključili da se „očigledno radi o zlonamernoj interpretaciji agencije DPA“ i insistirali da se $u$ indijskim listovima objave „pravilni“ izveštaji o pisanju Politike i vesti o tome kako se zvanično u Jugoslaviji ocenjuje indijska eksplozija. Istovremeno, od Saveznog sekretarijata je tražen integralni tekst Politike i predloženo je da predstavnik SSIP-a da izjavu za štampu u kojoj bi

\footnotetext{
${ }^{8}$ DA MSP, PA, Indija, 1974, fascikla 49, dosije 20, sign. 424319.

${ }^{9}$ Isto.

${ }^{10}$ Ovde se radi o pogrešno protumačenom stavu iz članka Đorđa Radenkovića obja-
} vljenog 23. maja. Radenković je opisao razvoj istraživanja, trenutno stanje i ekonomski značaj nuklearne energije u Indiji i posebno istakao da je Indija proglasila nuklearnu eksploziju za miroljubive svrhe odričući se proizvodnje oružja. Pomenuo je, međutim, i unutrašnje pritiske da Indija zbog bezbednosti i spoljnih pretnji iskoristi nuklearna dostignuća za izgradnju oružja, na koje je prema autorovom mišljenju indijska vlada rekla „ne“, svesna visokih troškova, međunarodnih posledica, ali i činjenice da bi nuklearno naoružavanje „kompromitovalo poziciju Indije kao ugledne nesvrstane zemlje i oslabilo njenu borbu za mir". Ђopђe Раденковић, „Да ли је опасан индијски атом?“, Полийика, 23. 5. 1974, 5. Osim ovog članka Politika je krajem maja u nekoliko navrata dala kratke informacije i tehničke podatke o indijskoj eksploziji, unutrašnjim političkim posedicama i o reagovanjima, posebno negati-

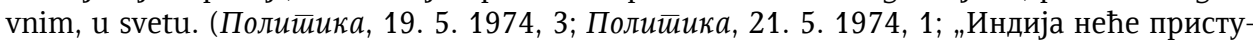
пити нуклеарном клубу“, Политичка, 22. 5. 1974, 3; „Нуклеарна искушења Индије“, Политиика, 24. 5. 1974, 5). 
se osudilo tendenciozno izveštavanje dopisnika DPA. Pre svega, zatražen je jugoslovenski zvanični stav, kako bi se „suzbili nepotrebni negativni komentari" i izašlo u susret očekivanom porastu interesovanja indijskih zvaničnika i novinara, zbog postojećih interpretacija. ${ }^{11}$

Jugoslovenska ambasada u Nju Delhiju je odmah na osnovu komentara Tanjuga pripremila bilten koji je poslala zvaničnicima, štampi, radiju i stranim ambasadama. Na osnovu toga, na radiju je istog dana javljeno da je Jugoslavija „podržala indijski stav oko nuklearne eksplozije“ i da je vodeći jugoslovenski list Politika javio da je „Indija postala šesta nuklearna sila, ali prva koja se odrekla njene upotrebe u vojne svrhe“. ${ }^{12}$ Jugoslovenski zvaničnici su poverovali tim uveravanjima i isticali da je eksperiment veliko dostignuće Indije na polju nauke, te da je značajno pošto je postignuto od zemlje u razvoju kojoj je nuklearna energija potrebnija nego mnogim drugim zemljama. Indijski stav da neće koristiti atomsku energiju u vojne svrhe bio je, prema jugoslovenskom tumačenju, na liniji njenog stava o zabrani korišćenja atomskog oružja, i u skladu sa stavom nesvrstanih zemalja, te ga je Jugoslavija u potpunosti podržavala. Na isti način je narednih dana pisala i indijska štampa, čime su negativne posledice prvih izveštaja o jugoslovenskom stavu bile prevaziđene i prema mišljenju jugoslovenskih diplomata, izbegnuto je da dati događaj bude smišljeno iskorišćen za „zabijanje klina između nesvrstanih". ${ }^{13}$

Jugoslovenska strana je polako formirala svoje stavove, na osnovu izjave indijske vlade o nuklearnoj eksploziji, pažljivog praćenja reagovanja $\mathrm{u}$ indijskoj javnosti i svetu i svoje opšte politike. Iz Kabineta zamenika saveznog sekretara inostranih poslova je 23. maja 1974. svim diplomatskim predstavništvima SFRJ poslata reakcija na indijsku nuklearnu eksploziju radi informacije i korišćenja. U depeši je stajalo: „Nuklearna eksplozija koju je izvršila Indija je vrlo važan događaj. To svedoči o velikom dostignuću prijateljske Indije na naučnom i tehnološkom polju, što zaslužuje utoliko veću pažnju jer se radi o zemlji u razvoju. Izjava indijske vlade i njena odluka da rezultate svojih nuklearnih istraživanja neće koristiti u vojne svrhe u skladu je sa principijelnim stavom o zabrani razvoja, proizvodnje, stacioniranja i korišćenja nuklearnog oružja koji zastupa Jugoslavija, držeći se dosledno stavova koje su o tome usvojile nesvrstane zemlje. Nuklearna energija će postajati sve značajniji faktor razvoja, što je najočigledniji način potvrdila i tzv. energetska kriza. U vezi s tim, treba imati u vidu i činjenicu da međunarodna

\footnotetext{
${ }^{11}$ DA MSP, PA, Indija, 1974, f. 46, dosije 5, sign. 425597.

12 Videti: Ђ. Раденковић, „Да ли је опасан индијски атом?“, Полийика, 23. 5. 1974, 5 .

${ }^{13}$ DA MSP, PA, Indija, 1974, f. 46, dosije 5, sign. 425548, 425597; DA MSP, PA, Indija, 1974, f. 47, dosije 2, sign. 425550.
} 
agencija za atomsku energiju nije ispunila očekivanja zemalja u razvoju u pogledu šireg korišćenja nuklearne energije u miroljubive svrhe, kao i da se odgovarajuće odredbe ugovora o neširenju nuklearnog oružja ne sprovodi $u$ život". ${ }^{14}$

Osnovne teze iznete $u$ ovoj depeši kasnije su ponavljane i razvijane i činile su okosnicu odnosa jugoslovenske diplomatije prema indijskoj nuklearnoj probi. Isticano je, dakle, da se radi o velikom i važnom dostignuću Indije na naučnom i tehnološkom polju i da je posebno značajno što je to dostignuće jedne zemlje $u$ razvoju, a zatim je u prvi plan stavljana izjava indijske vlade da postignute rezultate neće koristiti u vojne svrhe, što se poklapalo sa principijelnim stavovima Jugoslavije i nesvrstanih zemalja.

U široj elaboraciji značaja i posledica indijske nuklearne eksplozije koja je 27. maja iz Kabineta pomoćnika saveznog sekretara Miljana Komatine upućena svim diplomatskim predstavništvima, navodi se da je eksplozija „logičan rezultat višegodišnjih nastojanja Indije da ovlada nuklearnom tehnologijom“, a da je ovaj trenutak izabran zbog teške unutrašnje društveno-ekonomske situacije, straha od nuklearne moći Kine i pojačanog vojnog prisustva i angažovanja SAD i SSSR u Indijskom okeanu i na Potkontinentu. Indija je pokušala da eksplozijom okupira pažnju domaće javnosti i ojača poziciju vlade i nacionalno samopouzdanje, a spolja da pojača svoju međunarodnu poziciju i nezavisnost i da postane značajan vojni faktor. Eksplozija je posebno uticala na odnose sa Kinom, bila je upozoravajuća za Pakistan, komplikovala je proces normalizacije indijsko-američkih odnosa i značila je potencijalno osamostaljivanje Indije od vojne zavisnosti od SSSRa i pružala je Indiji jači položaj među velikim zemljama. Posledice eksplozije su bile posebno mnogostruke $u$ odnosu na Pokret nesvrstanih: pozicije Indije u pokretu su nesumnjivo ojačale i pojavljivale su se i ekonomske prednosti koje su mogle da budu iskorišćene $u$ perspektivi za ubrzavanje privrednog razvoja i transfer modernih tehnologija $u$ zemlje $u$ razvoju. Činjenica, međutim, da Indija kao jedan od utemeljitelja politike nesvrstavanja svoju bezbednost jača kroz nuklearno naoružavanje, nailazila je na negodovanje mnogih članica pokreta, ali i podsticala druge da same pristupe nuklearnim probama, što je narušavalo napore u pravcu razoružavanja. ${ }^{15}$

Stav Jugoslavije, „koji je s obzirom na njen položaj i prestiž bio od velikog značaja“, išao je za tim da ne oteža položaj Indije među nesvrstanim zemljama i da afirmiše njihovu solidarnost i veru u ciljeve politike nesvrstavanja, uz istovremeno pozivanje na zajedničke stavove o neširenju nuklearnog oružja. Jugoslavija je pri oceni indijskog koraka polazila od svojih principijelnih stavova o pravu svake zemlje da jača svoju bezbednost i

${ }^{14}$ DA MSP, PA, Indija, 1974, f. 47, dosije 2, sign. 424123, 445717.

${ }^{15}$ DA MSP, PA, Indija, 1974, f. 47, dosije 2, sign. 426027. 
nezavisnost, o razoružanju i nuklearnim probama, kao i o korišćenju nuklearne energije $u$ miroljubive svrhe od strane svih zemalja. Indijsko pozivanje na miroljubivi karakter eksplozije imalo je „prvenstveno politički značaj“, ali pružalo je jugoslovenskoj diplomatiji osnovu da u svom stavu pokaže razumevanje za Indiju, ne napuštajući jugoslovenske principijelne stavove o svim aspektima tog problema. ${ }^{16}$ I nešto kasnije je zamenik saveznog sekretara Jakša Petrić u razgovoru sa indijskim ambasadorom u Beogradu P. N. Menonom 31. maja 1974, na zahvaljivanje na podršci i pozitivno reagovanje jugoslovenske diplomatije i ponovno isticanje miroljubivog karaktera indijskih nuklearnih istraživanja, poručio da se Jugoslavija rukovodila činjenicom da joj je Indija prijateljska zemlja u čiju miroljubivu politiku ima potpuno poverenje, da već dugo prati indijska nuklearna istraživanja i da je „impresionirana nivoom njenih tehnoloških dostignuća“. Petrić je posavetovao Menona da je potrebno da Indija objasni svoj stav što većem broju zemalja, naročito nesvrstanih, kako ne bi došlo do nerazumevanja i nepravilnog shvatanja ciljeva indijskih nuklearnih istraživanja. ${ }^{17}$

Jugoslovenska strana je pažljivo i kontinuirano pratila reagovanja $u$ Indiji i u svetu i u odnosu na njih dalje formirala svoje stavove i nastupe na međunarodnoj sceni. Već 21. maja iz ambasade SFRJ u Nju Delhiju je javljano Beogradu da su „indijska javnost, štampa i pojedine vodeće ličnosti iz političkih partija sa oduševljenjem primili vest o uspešno izvedenoj nuklearnoj eksploziji“. Vlada i Kongresna stranka i naučnici koji su učestvovali u izvođenju eksplozije podvlače eksploziju kao veliko dostignuće ljudi nauke i naglašeno ističu miroljubivi karakter eksperimenta. Desničarske partije su pozdravljale eksploziju kao uspeh indijske nauke i „dugo očekivani i nepotrebno odlagani korak ka nuklearnom naoružanju Indije“. Partije levice su bile odmerenije, pozdravljale eksperiment kao naučni uspeh i korak ka smanjenju privredne i tehnološke zavisnosti Indije, ali su isticale da taj uspeh „ne može poslužiti vladi kao dimna zavesa za postojeće ekonomske i socijalne probleme“.

U prvim kontaktima ambasade sa ličnostima iz javnog i političkog života uočeno je da su reagovanja vremenom postajala odmerenija i izdiferenciranija i sve je bilo prisutnije iščekivanje kako će se eksplozija odraziti na odnose na Potkontinentu i na međunarodni položaj Indije, posebno na odnose sa Pakistanom. ${ }^{18}$

Upravo reakcija Pakistana na indijsku nuklearnu eksploziju bila je posebno važna u međunarodnim okvirima i jugoslovenska diplomatija joj je

${ }^{16}$ Isto.

${ }^{17}$ DA MSP, PA, Indija, 1974, f. 47, dosije 2, sign. 427316.

${ }^{18}$ DA MSP, PA, Indija, 1974, f. 49, dosije 21, sign. 424604; DA MSP, PA, Indija, f. 47 , dosije 2 , sign. 424960,425550 . 
posvetila značajnu pažnju. ${ }^{19}$ Načelnik VIII uprave SSIP-a Dževad Mujezinović razgovarao je već 21. maja 1974. sa ambasadorom Pakistana u Jugoslaviji Pashom koji je došao na sopstveno traženje i izložio stav pakistanske vlade o indijskoj nuklearnoj eksploziji i priložio zvaničnu izjavu pakistanske vlade od 18. i izvod iz govora premijera Zulfikara Ali Butoa na konferenciji za štampu 19. maja 1974. (istog dana su SSIP-u iz jugoslovenske ambasade u Islamabadu dostavljeni najvažniji stavovi iz vladine i premijerove izjave). Naime, Pakistan je „već duže vremena“ bio zabrinut zbog indijskih nuklearnih istraživanja, pažljivo ih je pratio i znao za mnoga dostignuća, pa je u raznim međunarodnim telima i OUN upozoravao na opasnost od razvoja indijskog nuklearnog potencijala i uopšte nije bio iznenađen indijskom nuklearnom eksplozijom. Posebno je isticano da se „probe ove vrste ne vrše samo u miroljubive svrhe" i da će indijska eksplozija imati vrlo ozbiljne posledice po razvoj odnosa na Indijskom potkontintetu i šire. Procenjujući indijske nuklearne kapacitete Pakistanci su zaključivali da bi od eventualnog indijskog nuklearnog napada "samo susedi bili ugroženi“, ali da indijska eksplozija treba da izazove zabrinutost čitavog čovečanstva, uprkos uveravanjima da je izvršena isključivo u miroljubive svrhe. ${ }^{20}$

Vlada Pakistana je smatrala da posedovanje nuklearnog oružja predstavlja „instrument pretnje, pritiska i ucene prema zemljama koje ne poseduju takvo naoružanje, ali da se neće povinovati toj pretnji niti prihvatiti hegemoniju i dominaciju Indije, niti pristati na bilo kakav kompromis na račun Kašmira“. Izvršena nuklearna proba ne pogađa samo zemlje koje ne raspolažu takvom moći, već istovremeno predstavlja pretnju široj međunarodnoj zajednici, kršeći sporazume o zabrani širenja i posedovanja i isprobavanja nuklearnog oružja iz 1968. i ohrabrujući neke zemlje Azije i Afrike da ulažu napore za ovladavanjem nuklearnim naoružanjem. Stoga je pakistanska vlada smatrala da treba ne samo osuditi indijsku nuklearnu eksploziju, već preduzeti i zajedničke akcije u cilju očuvanja interesa ugroženih zemalja. ${ }^{21}$

Pakistan je očekivao od velikih sila osiguranje političkih garantija protiv indijskih nuklearnih pretnji i vodio je međunarodnu akciju pokušavajući da internacionalizuje problem i obezbedi kolektivnu osudu Indije. Vlada Pakistana je upoznala Savet bezbednosti UN i uputila poruke premijera Butoa nuklearnim silama na zasedanju Saveta CENTO u Vašingtonu, a potom na sednici Komiteta za razoružanje u Ženevi, a u UNICEF-u je

${ }^{19}$ Već je pomenuto da su Indija i Pakistan vodili međusobne ratove 1947, 1965. i 1971. a posledice ovih sukoba i brojna sporna pitanja uticala su da obe zemlje pokrenu i ubrzaju vojne nuklearne programe. Videti napomenu 1.

${ }^{20}$ DA MSP, PA, Indija, 1974, f. 46, dosije 8, sign. 424043, 424831.

${ }^{21}$ DA MSP, PA, Indija, 1974, f. 46, dosije 8, sign. 424043, 424831. 
postavljeno i pitanje pomoći Indiji u narednih pet godina. Uspesi Pakistanaca su bili ograničeni, jer nijedan skup nije do kraja prihvatio njihove stavove, mada su izrečene određene kritike na račun Indije. Istovremeno, specijalne misije visokih funkcionera Pakistana su posećivale prestonice svih pet stalnih članica Saveta bezbednosti OUN, tražeći njihovu nuklearnu zaštitu, ocenjujući da se američki „kišobran“ kroz CENTO pokazao neefikasnim u ratu 1971. godine. Jugoslovenski diplomati su imali utisak da pakistanska akcija u celini nije naišla na odziv koji je Pakistan očekivao i da je većina zemalja vodila računa o svojim posebnim interesima. U toj akciji je uočavana i neprincipijelnost, jer je Pakistan nekoliko godina ranije pozdravio kineske nuklearne eksplozije. ${ }^{22}$ Pored toga, premijer Buto je u svojoj izjavi istakao i da će Pakistan pored traženja garancija od velikih sila istovremeno „pospešiti i napore na proizvodnji nuklearne energije, ali isključivo u miroljubive svrhe“, što su službenici jugoslovenske ambasade u Islamabadu uzimali sa rezervom, smatrajući da su ti napori usmereni „možda i ne samo u miroljubive svrhe“. Oni su na osnovu pakistanskih reagovanja zaključivali da indijska eksplozija vodi do „jačanja vojno-političkih aspekata i negativnog razvoja odnosa na Potkontinentu i šire u tom delu sveta“. ${ }^{23}$

Jugoslovenska diplomatija je pažljivo pratila intenzivna i raznovrsna reagovanja drugih zemalja na indijsku nuklearnu eksploziju. Krajem maja je uočavano da je, uprkos indijskim diplomatskim naporima u objašnjavanju karaktera eksplozije, preovladavala kritika u većini zemalja, neodobravanje ovog koraka i ocena da je eksplozija najmanje motivisana ciljevima miroljubivog korišćenja nuklearne tehnologije, mada je dozvoljavano da će služiti i u te svrhe. Bila je vidna saglasnost u oceni da su u prvom planu bili političko-psihološki i odbrambeni momenti (prema Kini, SAD, SSSR), kao i napor da se odvrati pažnja domaće javnosti sa teških unutrašnjih socijalnoekonomskih problema. Nije se očekivalo uključivanje Indije u dalju trku u nuklearnom naoružanju, jer bi to dalje iscrpljivalo ionako slabu privredu, ali nije bilo sumnje da je nuklearnom probom i praktično demonstrirala

22 DA MSP, PA, Indija, 1974, f. 46, dosije 8, sign. 424831; DA MSP, PA, Indija, 1974, f. 49, dosije 21, sign. 426183, Informacija o reagovanju u svetu na indijsku nuklearnu eksploziju, SSIP, 29. maj 1974. Prema informacijama jugoslovenske ambasade u Vašingtonu od 29. maja 1974, Stejt department je ocenjivao da je Pakistanu najteže palo što ga je indijska nuklearna eksplozija „vojno i tehnološki stavljala u permanentan inferioran položaj prema Indiji, te sada traži izlaz iz te situacije“, ali nije znao kako dati tražene garantije nenuklearnim zemljama i „umiriti strahovanja Pakistana“ (DA MSP, PA, Indija, 1974, f. 46, dosije 8, sign. 426890).

${ }^{23}$ DA MSP, PA, Indija, 1974, f. 46, dosije 8, sign. 424831. Pakistan je nastavio razvoj vojnog nuklearnog programa koji je započeo 1972, da bi stekao status nuklearne sile 1990. i izvršio prvi uspešan nuklearni test tek 1998. J. Hymans, Achieving Nuclear Ambitions, 3, 243-248. Više u: Bhumitra Chakma, Pakistan's Nuclear Weapons (New York: Routledge, 2009). 
svoje rezerve i neslaganja sa odredbama Sporazuma o neširenju nuklearnog oružja i otvorila sebi mogućnost da proizvodi i tu vrstu oružja kada oceni da joj je to neophodno. Postojalo je opšte uverenje da je Indija stvorila negativan presedan za više zemalja koje su i inače bile orijentisane na nuklearizaciju i koje će indijski slučaj koristiti kao povod za ostvarivanje svojih namera $u$ proizvodnji nuklearnog oružja (u tom kontekstu su pominjani Japan, SR Nemačka, Južna Afrika, Izrael, Egipat, Libija, Argentina, Kanada, Pakistan, itd.). ${ }^{24}$

Opšta ocena je bila da treba očekivati negativne posledice i komplikovanje odnosa na Indijskom potkontinentu i u Indijskom okeanu, gde je sada jačao i vojni uticaj Indije. S druge strane, izražavana je želja da velike nuklearne sile shvate indijsku eksploziju kao opomenu i poziv na pojačane napore da se konačno krene putem stvarne i isključive upotrebe nuklearne energije $u$ miroljubive svrhe i ubrza razvoj nedovoljno razvijenih zemalja. Posebno su pažljivo razmatrane reakcije nesvrstanih zemalja, koje su bile različite. Neke nesvrstane zemlje su bile kritički nastrojene i strahovale od posledica eksplozije, ali su se ograničavale na interne komentare i nisu izlazile sa javnim kritikama i osudama, smatrajući da se ne može osporavati pravo drugim zemljama da vrše eksplozije, sve dok to čine velike sile. Jedino su Indonezija i Peru dale vladine izjave u kojima je otvoreno izraženo žaljenje zbog eksplozije. Bilo je i stavova (Alžir, Gana) koji su dovodili u pitanje nesvrstan karakter Indije i u kojima je isticano da je "nanesena ozbiljna šteta miroljubivoj koegzistenciji i nesvrstanoj politici“. S druge strane, bilo je predstavnika nesvrstanih i zemalja u razvoju kod kojih je primećen „izvestan ponos što se zemlja kao Indija osposobila za takva dostignuća“, Brazil je podržao Indiju očekujući razvoj nuklearne saradnje sa njom, a bilo je i stavova da treba da postoji ,jedan opšti nuklearni miroljubivi program Nesvrstanih zemalja“. ${ }^{25}$

Važno je bilo i reagovanje NR Kine, posebno zato što su postojala i mišljenja da je indijska nuklearna proba bila prevashodno usmerena na pokazivanje snage Kini. Kina nije prihvatala indijsko objašnjenje o miroljubivom karakteru eksplozije, i u tome je videla potvrdu svoje teze o neodrživosti sporazuma o neširenju nuklearnog oružja. Iako je smatrala da eksplozija podstiče "indijske hegemonističke pretenzije na Potkontinentu i šire" nije javno reagovala niti je odustajala od orijentacije na normalizaciju odnosa sa Indijom, „kada ova pređe sa reči na dela u odnosima prema Kini“. Istočnoevropske zemlje su smatrale da je eksplozija izvršena prvenstveno „radi uspostavljanja ravnoteže u odnosima Indije sa Kinom“ i isticale

${ }^{24}$ DA MSP, PA, Indija, 1974, f. 49, dosije 21, sign. 426183, Informacija o reagovanju u svetu na indijsku nuklearnu eksploziju, SSIP, 29. maj 1974.

${ }^{25}$ Isto. 
da širenje nuklearnog oružja dalje komplikuje međunarodne odnose, ali i da je to realnost sa kojom se mora računati. Sa njihove strane je smatrano da eksplozija nije išla u prilog pozicijama i namerama SSSR-a prema Indiji i da je slabila značaj Sporazuma o sovjetsko-indijskoj saradnji, jer je faktički „osujećivala intenciju SSSR-a da Indiju drži pod svojim nuklearnim 'kišobranom'". ${ }^{26}$

Od zapadnih zemalja najoštrije je reagovala Kanada koja je preduzimala više konkretnih mera prema Indiji (preispitivanje nuklearne saradnje, konsultacije sa drugim vladama, traženje objašnjenja od Indije o izvoru plutonijuma, suspendovanje isporuke nuklearne opreme i sirovina, povlačenje predstavnika iz Agencije za atomsku energiju iz Bombaja, odbijanje zahteva Indije za odlaganje komercijalnih dugova, razmatranje programa pomoći u hrani i poljoprivredi, itd.). Indijci su, s druge strane, ocenjivali da će se Kanada „vrlo brzo smiriti“. Zabrinutost su iskazali i Japan i generalni sekretar OUN Kurt Valdhajm. SAD su izjavljivale da su protiv širenja nuklearnog oružja, koje je imalo negativan uticaj na stabilnost u svetu, ali nisu bile kategorične u osudi, mada je postojala bojazan da bi Kongres mogao da odbije pomoć Indiji. Insistirano je da Indija u interesu svih zemalja odustane od daljih nuklearnih eksplozija. Stejt department je odbacivao indijska objašnjenja da je eksplozija izvršena u mirnodopske svrhe. Amerikanci su odbijali i nastojanja Pakistana da nuklearne sile daju posebne garantije nenuklearnim zemljama, očekivali su dalji razvoj situacije, razvoj odnosa Indije sa Kinom i SSSR-om i nastojale da eksplozija ne zaustavi započeti proces popravljanja odnosa sa Indijom.

Vlade Velike Britanije, Australije i Novog Zelanda su izrazile zabrinutost zbog mogućih negativnih posledica, ali nisu želele da javno „podižu preveliku prašinu“. Jedino je Francuska čestitala i „argumentovano branila indijsku eksploziju, čak i ako je u vojne svrhe“, jer je, kako je ocenjivano, u junu predstojala serija njenih eksperimenata. Francuska je odbacivala i prigovore na račun siromaštva Indije, smatrajući da ni SSSR i Kina nisu bile u boljoj ekonomskoj situaciji, pa su ipak prioritetno trošili sredstva za izradu atomskog oružja. ${ }^{27}$

${ }^{26}$ Isto. O sovjetsko-indijskim odnosima po pitanju nuklearnog programa videti: Balasz Szalontai, „The Elephant in the Room: The Soviet Union and India's Nuclear Program 1967-1989“, Nuclear Proliferation International History Project, Working Paper 1, November 2011. Woodrow Wilson International Center for Scholars. http://www.wilsoncenter.org/npihp (pristupljeno 21. 10. 2015).

${ }^{27}$ DA MSP, PA, Indija, 1974, f. 49, dosije 21, 426183, Informacija o reagovanju u svetu na indijsku nuklearnu eksploziju, SSIP, 29. maj 1974; Isto, sign. 426719; DA, MSP, PA, Indija, 1974, f. 46, dosije 8, sign. 426890; DA MSP, PA, Indija, 1974, f. 47, dosije 2, sign. 425550 . 
U izveštajima jugoslovenskih diplomata isticano je i da mnogi diplomati zapadnih (Švedska, Švajcarska, V. Britanija) i istočnoevropskih zemalja (Poljska, Mađarska, DR Nemačka) na indijsku nuklearnu eksploziju gledaju izrazito kritički i sa ironijom aludirajući na trošenje velikih sredstava u uslovima teških unutrašnjih socijalno-ekonomskih problema i smatrajući da je eksplozija izvršena da bi se skrenula pažnja javnosti sa tih problema. ${ }^{28}$

Posebno važan deo jugoslovenske reakcije na indijsku nuklearnu eksploziju maja 1974. bilo je očekivanje jačanja saradnje u oblasti nuklearne energije, kako između Indije i Jugoslavije, tako i među nesvrstanim zemljama uopšte. U svakom slučaju, od saradnje sa Indijom u oblasti nuklearne energije mnogo veće interese i očekivanja imala je jugoslovenska strana. Zato su jugoslovenski predstavnici mnogo više insistirali na tome, dok su Indijci na rečima izražavali spremnost za saradnju, i ostavljali to pitanje stručnjacima.

Zamenik saveznog sekretara Jakša Petrić je već 31. maja 1974. indijskom ambasadoru Menonu na kraju razgovora izrazio uverenje da će Indija „upravo zato što je ovaj veliki rezultat ostvarila kao nesvrstana zemlja moći da i u ovoj oblasti sarađuje sa nesvrstanima i da im svoja naučna dostignuća stavi na raspolaganje“" ${ }^{29}$ Isto tako, i predsednik Josip Broz Tito je posle eksplozije i poruke Indire Gandi da Indija nema nameru da nuklearnu energiju koristi u vojne svrhe i spremnosti da sa svojim dostignućima upozna i nesvrstane zemlje, odgovorio da Jugoslavija ima interes za saradnju sa Indijom i upoznavanje njenih iskustava u rešavanju „tehnoloških problema proizvodnje nuklearnog materijala" i "tehničkih problema vezanih za organizaciju i način izvođenja miroljubivih nuklearnih proba“" ${ }^{30}$

Ambasador Topalovski je po povratku iz Jugoslavije 7. avgusta 1974. posetio Indiru Gandi, preneo joj Titove pozdrave i ponovio jugoslovensku „bezrezervnu podršku“ Indiji po pitanju nuklearne eksplozije. Jugoslavija je indijsko dostignuće smatrala uspehom svih nesvrstanih i bila je spremna da sa Indijom sarađuje na bilateralnoj i široj osnovi. Indira Gandi je sa zadovoljstvom primila informaciju o Titovom angažovanju kod više zemalja u „odbrani prava Indije da koristi atomsku energiju u miroljubive svrhe" i izrazila spremnost na saradnju sa Jugoslavijom i drugim zemljama.

${ }^{28}$ DA MSP, PA, Indija, 1974, f. 46, dosije 9, sign. 423959; DA MSP, PA, Indija, 1974, f. 49, dosije 21, sign. 426183, Informacija o reagovanju u svetu na indijsku nuklearnu eksploziju, SSIP, 29. maj 1974.

${ }^{29}$ DA MSP, PA, Indija, 1974, f. 47, dosije 2, sign. 427316.

${ }^{30}$ DA MSP, PA, Indija, 1974, f. 49, dosije 20, sign. 461112; DA MSP, PA, Indija, 1974, f. 46, dosije 9, sign. 430262; Arhiv Jugoslavije (AJ), fond Kabinet Predsednika Republike, 837, KPR, I-1/409, Poruka I. Gandi Titu 12. 6. 1974. i Titov odgovor 24. 7. 1974. 
Okvire te saradnje je trebalo utvrditi u kontaktima političara dve zemlje, ali je preciziranje i sprovođenje saradnje, prema njenom mišljenju, trebalo ostaviti stručnjacima. ${ }^{31}$

Kod Josipa Broza Tita je indijska eksplozija i razmena ponuda za saradnju u toj oblasti, izgleda, pobudila velika očekivanja i podstakla iznenadno oživljavanje nuklearnih vojnih ambicija, koje su postojale od kraja 40-ih godina, ali su jenjavale sredinom 60 -ih godina, zajedno sa interesom za nuklearna istraživanja uopšte, i nestala gašenjem Savezne komisije za nuklearnu energiju 1971. godine. ${ }^{32}$ Naime, već nekoliko nedelja posle indijske nuklearne eksplozije Tito je na sednici Predsedništva SFRJ jula 1974. odlučio da se ponovo pokrenu nuklearna istraživanja u mirnodopske svrhe, ali i u cilju proizvodnje nuklearnog oružja, okupio stručnjake iz jugoslovenskih instituta koji su se bavili nuklearnom energijom i zatražio od njih da brzo i precizno formulišu stavove o mogućnostima i potrebama za razvoj nuklearnih istraživanja u mirnodopske, ali i vojne svrhe. ${ }^{33}$ Prema svedočenju jednog od stručnjaka koji su bili prisutni na sastanku jula 1974, dr Ive Šlausa direktora Instituta „Ruđer Bošković“ u Zagrebu, Tito je rezolutno zatražio od okupljenih da naprave atomsku bombu. Šlaus, koji je malo kasnije otišao u SAD, smatra da se radilo ili o Titovoj „megalomanskoj ideji“ ili o "političkom blefu“. ${ }^{34}$

Međutim, po Titovom naređenju i pod okriljem Saveznog sekretarijata za narodnu odbranu, tim nuklearnih stručnjaka je oktobra 1974. izradio elaborat "O razvoju nuklearne energije u Jugoslaviji“ pod nazivom „Zadatak Kozara“. U elaboratu su detaljno iznete mogućnosti i potrebe Jugoslavije za mirnodopskim korišćenjem nuklearne energije, ali i za proizvodnjom nuklearnog oružja, predstavljeno trenutno stanje i značaj međunarodne saradnje za intenziviranje nuklearnih istraživanja. Pored toga, od jugoslovenske ambasade $\mathrm{u}$ Indiji je novembra 1974. dobijen materijal „Jugoslovensko indijska saradnja na području atomske energije“ u kojem je detaljno predstavljen istorijat nuklearnih istraživanja u Indiji, izloženi

${ }^{31}$ DA MSP, PA, Indija, 1974, f. 46, dosije 4, sign. 438436.

${ }^{32}$ O ovome više u: J. Hymans, Achieving Nuclear Ambitions, 172-196; Jacques E. C. Hajmans, „Proliferation Implications of Civil Nuclear Cooperation: Theory and a Case Study of Tito's Yugoslavia“, Security Studies, Vol. 20, No. 1 (March 2011), 85-99; Пола века

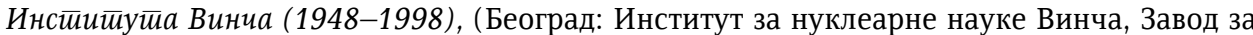
уџбенике и наставна средства, 2000), 32-37; AJ, fond Savezna komisija za nuklearnu energiju, 177-21, Položaj i zadaci Savezne komisije za nuklearnu energiju, 9. februar 1970.

${ }_{33}$ AJ, fond Predsedništvo SFRJ, 803-22, Stenografske beleške sa sednice Predsedništva SFRJ, 10. januar 1975.

34 J. Hymans, Achieving Nuclear Ambitions, 197; J. E. C. Hajmans, „Proliferation Implications of Civil Nuclear Cooperation: Theory and a Case Study of Tito's Yugoslavia“, 100; William Poter, Djuro Miljanic, and Ivo Slaus, „Tito's Nuclear Legacy“. Bulletin of the Atomic Scientists, Vol. 56, No. 2 (March-April 2000), 63-70. 
trenutni kapaciteti, analizirana prva nuklearna eksplozija i njene posledice i, posebno, doprinos međunarodne saradnje indijskom nuklearnom uspehu i mogućnosti saradnje Jugoslavije i Indije u cilju razvoja jugoslovenskih nuklearnih istraživanja. O ovim materijalima je raspravljalo Predsedništvo SFRJ u više navrata krajem 1974. i početkom 1975. godine. U materijalima i raspravama je pre svega jasno isticano da je osnovni povod pokretanja ovog pitanja bila indijska nuklearna eksplozija maja 1974. Potom je naglašeno jugoslovensko zaostajanje na polju nuklearnih nauka nastalo posle posustajanja nuklearnih istraživanja i gašenja Savezne komisije za nuklearnu energiju, odluka da se nuklearna istraživanja obnove, ali i nedostatak kapaciteta za ponovno pokretanje takvog projekta. Nabrajane su sve teškoće da Jugoslavija, pre svega njena privreda, realizuje tako skup i naučnotehnološki zahtevan projekat, ali jasno su ispoljena i očekivanja od saradnje sa prvom nesvrstanom nuklearnom silom Indijom, ali i sa drugim nesvrstanim zemljama koje su imale nuklearne ambicije i dovoljno novca da finansiraju zajednička istraživanja (isticane su Egipat, Iran i Libija). Na prvom mestu je razmatrana saradnja sa Indijom i u više diplomatskih kontakata je traženo da se u okviru ekonomske saradnje ispitaju mogućnosti saradnje na izgradnji nuklearnih centrala i razvoja istraživanja u oblasti nuklearne tehnologije i tehnike. Pre svega, radilo se o pomoći naprednije Indije Jugoslaviji, ali i o zajedničkom nastupanju na tržištima trećih, nerazvijenih, posebno nesvrstanih zemalja. ${ }^{35}$

Da bi se direktno upoznala indijska nuklearna dostignuća i ispitale mogućnosti saradnje Jugoslavije, Indije i drugih nesvrstanih zemalja, organizovana je poseta nuklearnih naučnika Indiji, koja je planirana za decembar 1974, a realizovana je od 9. do 20. januara 1975. Delegaciju su činili dr Milan Osredkar, direktor Instituta „Jožef Štefan“ u Ljubljani, dr Zdenko Dizdar, direktor Instituta „Boris Kidrič“ u Vinči, Janko Dumanović direktor Instituta za primenu nuklearne energije u poljoprivredi u Zemunu, dr Petar Štrohal naučni savetnik Instituta „Ruđer Bošković“ u Zagrebu i Radovan Ilić, major JNA. ${ }^{36}$ Tokom boravka u Indiji posetili su najvažnije naučne i privredne institucije i postrojenja iz oblasti nuklearne energije (institute i

${ }^{35}$ AJ, fond Savezni komitet za nauku i kulturu, 320-49-73, „Jugoslovensko indijska saradnja na području atomske energije", str. pov., New Delhi, oktobar 1974 (Isto i u: DA MSP, PA, Indija, 1974, f. 46, dosije 6, sign. 455659); AJ, 803-21, „O razvoju nuklearne tehnologije u Jugoslaviji“, str. pov., državna tajna, SSNO, oktobar 1974; AJ, 803-21, Stenografske beleške sa sednice Predsedništva SFRJ, 4. decembra 1974; AJ, 803-22, Stenografske beleške sa sednice Predsedništva SFRJ, 10. januara 1975; DA MSP, PA, Indija, 1974, f. 46, dosije 9, sign. 446792; DA MSP, PA, Indija, 1974, f. 48, dosije 14, 461759; DA MSP, PA, Indija, 1974, f. 49, dosije 20, sign. 432642.

36 DA MSP, PA, Indija, 1974, f. 49, dosije 20, sign. 458461, 458763, 459056, 461112,461455 . 
laboratorije, reaktore, elektrane i pogone za proizvodnju nuklearnog goriva, materijala, itd.) i razgovarali sa istaknutim naučnicima, privrednicima i političarima (između ostalih i sa predsednikom komisije za atomsku energiju dr Homi Sethnom). Delegacija je stekla veoma pozitivne utiske, posebno na polju izgradnje atomskih centrala i prateće industrije koju su razvili Indijci. Tokom razgovora je ponovljena spremnost za uzajamnu saradnju i zajednički nastup na trećim tržištima. Međutim, očekivanja od konkretne indijske pomoći, posebno u realizaciji probuđenih vojnih nuklearnih ambicija, nisu ispunjena. Indijci su ispoljili određene rezerve i preduslove saradnje: bila je neophodna politička odluka na najvišem nivou; definisanje jugoslovenskog dugoročnog nuklearnog programa; formiranje stručne kompetentne i ovlašćene institucije koja bi koordinisala rad na nuklearnom programu i nastupala sa jugoslovenske strane u odnosima sa Indijom (kakva je bila Savezna komisija za nuklearnu energiju); sklapanje novog ugovora o nuklearnoj saradnji (kakav je sklopljen 1965. i istekao 1970); tek potom se moglo pristupiti konkretnim oblicima saradnje koje bi utvrdili stručnjaci. Indijci su bili suzdržani i po pitanju uključivanja drugih nesvrstanih zemalja u saradnju. S druge strane, članovi jugoslovenske delegacije su već prilikom povratka iz Indije posetili druge nesvrstane zemlje radi ispitivanja mogućnosti saradnje sa njima na polju eksploatacije nuklearnih sirovina i korišćenja nuklearne energije $\mathrm{u}$ razne svrhe: Dizdar i Strohal su posetili Egipat, Dumanović Indoneziju, a Osredkar i Ilić nisu otišli u Iran zbog zauzetosti iranske strane. ${ }^{37}$

Pitanje nuklearne saradnje Jugoslavije i Indije je bilo prisutno i kasnije tokom 1975. ali bez konkretnih rezultata. U Nju Delhiju je u okviru zasedanja mešovitog komiteta za ekonomsku saradnju između Jugoslavije i Indije 12. februara 1975. sklopljen sporazum dveju vlada o naučnotehničkoj saradnji koji su potpisali potpredsednik SIV-a dr Antun Vratuša i ministar spoljnih poslova Indije Čevan. Sporazumom je predviđana razmena naučnika, stipendista, informacija, dokumentacije, projekata između dve zemlje, itd. Tom prilikom, kao i tokom zasedanja mešovitog komiteta o ekonomskoj saradnji, nisu ispunjena očekivanja jugoslovenske strane da se detaljnije razmotre mogućnosti saradnje $\mathrm{u}$ oblasti nuklearne energije. ${ }^{38} \mathrm{I}$ prilikom posete člana Predsedništva SFRJ Vidoja Žarkovića Indiji marta 1975. u razgovoru sa Indirom Gandi pominjana je saradnja u oblasti nuklearne energije. Indijska premijerka je pažljivo saslušala Žarkovićeve stavove

${ }^{37}$ AJ, 320-8-13, Informacija u vezi sa posetom jugoslovenskih naučnika Indiji, str. pov., SIV, 7. februar 1975; AJ, 320-49-73, Izveštaj o poseti jugoslovenskih naučnika Indiji, Egiptu i Indoneziji, 7. februar 1975; DA MSP, PA, Indija, 1974, f. 49, dosije 20, 45827; DA MSP, PA, Indija, 1975, f. 46, dosije 37, 4400, 42758.

${ }^{38}$ DA MSP, PA, Indija, 1975, f. 44, dosije 3, 47321. 
o potrebi saradnje nerazvijenih zemalja radi izbegavanja daljeg zaostajanja, ali nije komentarisala bilateralne aspekte nuklearne saradnje Jugoslavije i Indije. Akcenat je stavljala na teškoće koje je Indija i dalje imala u vezi sa obezbeđivanjem razumevanja za svoju prvu nuklearnu eksploziju, pre svega kod razvijenih zemalja (Kanade, SAD, SSSR i Zapadne Nemačke). Prijateljstvo sa Jugoslavijom je više posmatrala kroz njenu podršku i pomoć da se ta situacija prevaziđe, nego kroz razvoj nuklearne saradnje. Edvard Kardelj je na sednici Predsedništva SFRJ prilikom analize izveštaja o Žarkovićevom putu u Indiju, jasno uočio u držanju Indire Gandi rezervisanost, tako da je zaključio da se, pored pritiska na Indiju da do saradnje dođe, mora učiniti više napora na unutrašnjem polju. ${ }^{39}$

Može se zaključiti da je indijska nuklearna eksplozija direktno dovela do obnove jugoslovenskih nuklearnih ambicija i do niza koraka usmerenih ka uspostavljanju saradnje sa Indijom i drugim nesvrstanim zemljama i izvlačenju koristi iz njenih dostignuća i iskustava za sopstvene nuklearne planove, pa i one usmerene ka ovladavanju tehnologijom nuklearnog oružja. Jugoslovenska očekivanja od ove saradnje se nisu ispunila, posebno ona nerealna i preambiciozna vojna. Jedini rezultati su bili ponovno formiranje centralne institucije zadužene za nuklearnu energiju, pokušaj obnove materijalne i kadrovske osnove za istraživanja i formulisanje i pokretanje novog nuklearnog programa, koji je u civilnoj sferi dao izvesne rezultate, a u vojnoj sferi je istrajavao na nerealnim ambicijama do potpunog kolapsa. ${ }^{40}$

${ }^{39}$ AJ, 803-23, Izveštaj o poseti Vidoja Žarkovića Indiji; Zabeleška o razgovoru sa I Gandi, 2. mart 1974; Stenografske beleške sednice Predsedništva SFRJ, 12. mart 1974.

${ }^{40}$ Videti o tome: J. Hymans, Achieving Nuclear Ambitions, 197; J. E. C. Hajmans, „Proliferation Implications of Civil Nuclear Cooperation: Theory and a Case Study of Tito's Yugoslavia“, 3, 100; W. Poter, Dj. Miljanic, I. Slaus, „Tito’s Nuclear Legacy“, 63-70. U navedenim radovima se smatra da je jugoslovenski vojni nuklearni program postojao i posle Titove smrti, skoro do kraja postojanja države, odnosno do 1987. godine. 
Arhiv Jugoslavije (AJ), fond 177 Savezna komisija za nuklearnu energiju; 320 Savezni komitet za nauku i kulturu; 803 Predsedništvo SFRJ; 837 Kabinet Predsednika Republike.

Diplomatski arhiv Ministarstva spoljnih poslova Republike Srbije (DA MSP), Politička arhiva (PA), Indija, 1974, 1975; Jugoslavija, 1974.

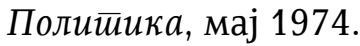

Bogetić Olivera, i Dragan Bogetić. Nastanak i razvoj pokreta nesvrstanosti. Beograd: Eksport pres, 1981.

Chakma, Bhumitra. Pakistan's Nuclear Weapons. New York: Routledge, 2009.

Chengappa, Raj. Weapons of Peace: the Secret Story of India's Quest to be a Nuclear Power. New Delhi: Harper Collins Publishers, 2000.

Čavoški, Jovan. Jugoslavija i kinesko-indijski konflikt 1959-1962. Beograd: INIS, 2009.

Hajmans, Jacques E. C. „Proliferation Implications of Civil Nuclear Cooperation: Theory and a Case Study of Tito's Yugoslavia“. Security Studies, Vol. 20, No. 1 (March 2011), 73-104.

Hymans, Jacques E. C. Achieving Nuclear Ambitions. Scientists, Politicians, and Proliferation. New York: Cambridge University Press, 2012.

Itty, Abraham. The Making of the Indian Atomic Bomb. Science, Secrecy, and the Postcolonial State. London and New York: Zed Books, 1998.

Макеgонска енииклойеguја, 2. Редактор Блаже Ристовски. Скопје: MAHУ, 2009.

Perkovich, George. India's Nuclear Bomb: The Impact On Global Proliferation. Berkeley, Los Angeles and London: University of California Press, 1999.

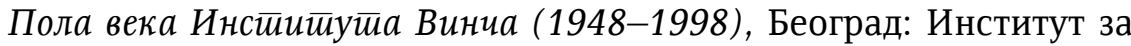
нуклеарне науке Винча. Завод за уџбенике и наставна средства, 2000.

Poter William, Djuro Miljanic, and Ivo Slaus, „Tito's Nuclear Legacy“. Bulletin of the Atomic Scientists, Vol. 56, No. 2 (March-April 2000), 63-70.

Szalontai, Balasz. „The Elephant in the Room: The Soviet Union and India's Nuclear Program 1967-1989“, Nuclear Proliferation International History Project, Working Paper 1, November 2011. Woodrow Wilson International Center for Scholars. http://www.wilsoncenter. org/npihp (pristupljeno 21. 10. 2015).

http://nuclearweaponarchive. org/India/index. html (pristupljeno 18. 10. 2015). 
Dragomir Bondžić

INDIA'S 1974 NUCLEAR TEST - REACTIONS IN YUGOSLAVIA

\section{Summary}

After years-long research, Indian scientists carried out a successful nuclear explosion on May 18, 1974 in the Rajastan desert. Although Indian officials immediately stated that it was a "peaceful nuclear explosion“, and that they did not intend to make a nuclear weapon, India had become the $6^{\text {th }}$ nuclear power and the first non-aligned country to come into "the nuclear club". This lead to a strong criticism on the international stage, especially by Pakistan, as well as by great powers and some non-aligned countries. As a member of the Non-aligned Movement, closely alligned with India, Yugoslavia carefully tracked statements and explanations given by Indian officials, systematically noted and analyzed responses of individual countries, and calmly created its own view toward the Indian nuclear test. Yugoslav diplomacy promptly congratulated India its huge technological success, defending the right of all countries, including India, to develop research in the field of nuclear energy, thereby granting full trust to Indian official statements that they did not intend to use their achievements in military purposes. Further, the Indian nuclear explosion resurected the previous nuclear ambitions of Yugoslav state leadership, primarily of Josip Broz Tito. The Yugoslav nuclear program was relaunched, including the examination of possibilities for exploiting nuclear energy for military purposes. Yugoslav leaders expected great help from India in this matter, so they undertook efforts to intensify cooperation between the two countries in the field of nuclear energy, and to spread that cooperation to other nonaligned countries. However, Indian assistance, being much less than expected, did not contribute to the Yugoslav nuclear program, which, owing to many weaknesses, produced modest results in civilian research, and did not achieve any success in the military field.

KEYWORDS: Yugoslavia, India, atomic bomb, nuclear test, "peaceful nuclear explosion", Non-aligned movement, Josip Broz Tito 


\section{ИНДИЙСКОЕ ЯДЕРНОЕ ИСПЫТАНИЕ 1974 ГОДА - ОТКЛИКИ В ЮГОСЛАВИИ}

\section{Резюме}

После многолетних исследований 18 мая 1974 года индийские учёные провели успешные ядерные испытания в пустыне Раджастан. Несмотря на то что индийские официальные лица сразу заявили что это был «взрыв в мирных целях», и что они не собираются создавать оружие, Индия стала шестой атомной державой и первым неприсоединившимся государством, которое стало членом «атомного клуба». Это событие вызвало острую реакцию на международной сцене, особенно со стороны Пакистана, а также великих держав и некоторых неприсоединившихся стран. Как член Движения неприсоединения, близкое и дружественное Индии государство, Югославия внимательно отслеживала заявления и объяснения индийских официальных лиц, анализировала реакцию на них некоторых стран и постепенно формулировала свою позицию в отношении индийских атомных испытаний. Югославские дипломаты поздравили Индию с большим научоно-техническим достижением и выступили в защиту права всех государств, в том числе и Индии, проводить исследования в области ядерной энергетики, выразив полное доверие заявлениям индийских официальных лиц о том, что они не намерены использовать свои достижения в военных целях. Кроме того, индийский атомные испытания снова пробудили прежнее амбиции югославских государственних руководителей, и прежде всего, Йосипа Броз Тито. Вскоре была возобновлена югославская ядерная программа, в рамках которой, в том числе, изучались возможности использования энергии атома в военных целях и для производства ядерного оружия. В этом югославские руководители ожидали большой помощи со стороны Индии, предпринимая попытки интенсификации двухстороннего сотрудничества в области ядерной энергетики и расширения этого сотрудничества на другие неприсоединившиеся государства. Однако, помощь Индии не соответствовала ожиданиям и не внесла решающего вклада в югославскую ядерную программу, которая изза многочисленных проблем дала скромные результаты, и не имела никакого успеха в военном отношении.

КЛЮЧЕВЫЕ СЛОВА: Югославия, Индия, атомная бомба, ядерные испытания, «использование атомной энергии в мирных целях», Движение неприсоединения, Йосип Броз Тито 